\title{
THE INFLUENCE of COPING STRATEGIES, SOCIAL SUPPORT and DEMOGRAPHIC FACTORS on PSYCHOLOGICAL WELL-BEING Of OVERSEAS STUDENTS SYARIF HIDAYATULLAH STATE ISLAMIC UNIVERSITY JAKARTA
}

\author{
Ahmad Faisal $^{1}$, Diana Mutiah ${ }^{2}$ \\ \{Ahmad.faisal14@mhs. uinjkt.ac.id, diana.mutiah@uinjkt.ac.id\} \\ ${ }^{1,2}$ Fakultas Psikologi, Universitas Islam Negeri Syarif Hidayatullah Jakarta
}

\begin{abstract}
This research was conducted to determine the effect of coping strategy (problem-focused coping, emotion focused coping and less useful coping), social support (appraisal, tangible and belonging) and demographic factors (semester, gender and social status) on the psychological well-being of overseas students from the Syarif Hidayatullah State Islamic University. Respondents in this study amounted to 232, who were active students of the Syarif Hidayatullah State Islamic University from outside Jakarta, Bogor, Depok, Tangerang and Bekasi. The sampling technique used is a non-probability sampling technique, namely convenience sampling. Hypothesis testing with multiple regression analysis and using SPSS v.21.0 software. The results of the study using multiple regression analysis showed that the coping strategy variables, social support and demographic factors used had an effect of $45.7 \%$ on psychological well-being overseas students of the Syarif Hidayatullah State Islamic University. The results of the analysis of each variable separately show that there are four variables that significantly influence psychological well-being, namely emotion-focused coping, less useful coping, tangible and belonging.
\end{abstract}

Keyword: Psychological Well-Being, Coping Strategy, Social Support, Demographic Factors, Overseas Students. 


\section{Introduction}

Many State Universities in Indonesia are still in big cities. This makes many people decide to study at a higher education level outside their home region within a certain period of time and at their own volition or referred to as overseas students [1]. Individuals' migration from their original area to a new area that causes overseas students to be required to adaptation to his new environment. According to Bowman, to be adapting in the new environment, overseas students must have psychological well-being [2]. Because if overseas students are not able to adapt to their new environment they have the potential to experience the negative effects of culture shock, namely stress, depression and frustration [3].

Huppert explains that by having psychological well-being, overseas students will be able to run their lives well [4]. This is because by having psychological well-being, individuals will have a feeling of happiness, confidence and affection so that they avoid stress, depression and frustration. In addition, everyone has control over them, has a purpose in life, is involved in activities that develop their potential and have a positive relationship with others. Another positive impact obtained by overseas students is that having a good psychological well-being is having good academic performance [5].

To be able to have a good psychological well-being, overseas students need to try to change cognitive and behaviors continuously to manage external and internal demands that are considered burdensome or exceed resources, which are called coping strategies [6]. Gustem-Carnicer \& Calderón states that coping strategies have an important role in psychological well-being [7]. Some researcher explains more specifically that the use of coping strategies by taking positive actions, acting planned and receiving feelings have a positive effect on psychological well-being [8], [9]. In the research of Gloria one of the most widely used coping strategies is to seek assistance in the form of solutions to problems from other individuals [8]. This indicates that not only coping strategies have an important influence on the psychological well-being, there are other things such as social support.

Social support is the provision of comfort, attention, appreciation, or assistance that comes from individuals or other groups. Further explained by Cohen \& Hoberman, social support is a variety of resources derived from relationships between individuals [10]. Social support can be provided by partners, family, friends, doctors, or community organizations, with this in mind that individuals are expected to feel loved, valued and recognized as part of their social community, so that individuals feel that support is always there for them [11].

Many research found that social support has an influence on individual psychological well-being [12], [13], [14]. Previous research explained that the higher the social support provided, the higher the level of psychological well-being students [14], [15]. This also causes social support as one of the most important components for psychological well-being overseas students [29], [30].

In addition to coping strategies and social support other factors that affect psychological well-being in overseas students, namely demographic factors such as semester, gender and social status [15], [16]. Semester is a calculation of time since students enter the University. Bewick et al. stated that students experienced a decrease in psychological well-being during their education at the University [17]. The study also explained, when in the second semester the psychological well-being of students decreased by $30 \%$ compared to the first semester. The decrease in psychological well-being of students also occurred in semesters three, four, five and six, but the magnitude of the decline was less than the decline that occurred in the second semester to semester one.

The next demographic factor is gender, Adelman [17] found that men had higher psychological well-being scores than women. It is inversely proportional to Momtaz et al. [18] who found women had a higher wellbeing score than men. The last factor that is considered influential on Psychological well-being is social status. Social status can include education, income and work positions. Ahrens \& Ryff states that the level of income affects the psychological well-being [19]. Ryff \& Singer state that income that is more specific such as family income has a significant effect on psychological well-being. In this study, social status is in the form of parents' income level [20].

Based on the phenomena and factors that have been explained, the author is interested in conducting a study related to "The Influence of Coping Strategies, Social Support and Demographic Factors on Psychological Well-Being of Overseas Students Syarif Hidayatullah State Islamic University Jakarta". 


\section{Method}

\subsection{Participant}

The samples from the study were active students of Syarif Hidayatullah State Islamic University from outside Jakarta, Bogor, Depok, Tangerang and Bekasi. The method of selecting samples using convenience sampling is a sampling technique based on consideration of the convenience and availability of individuals to be sampled.

\subsection{Measures}

Demographic. The demographic data collected is semester, gender and parents' income.

Psychological well-being. Psychological well-being was measured using the Ryff Scale of Psychological Wellbeing [21]. This scale has six dimensions, namely self-acceptance, positive relationships with others, autonomy, environmental mastery, purpose in life and personal growth. In each dimension consists of three items. Where each item has four choices of answers, namely strongly agree, agree, disagree, and strongly disagree.

Coping strategies. The coping strategies was measured using brief [22]. This scale consists of three dimensions, namely problem-focused coping, emotion-focused coping and less useful coping. There are 28 items on this scale with four choices of responses, i.e. never, sometimes, often and very often.

Social support. Social Support is measured using the Interpersonal Support Evaluation List-12 [22]. This scale consists of three dimensions, namely appraisal, tangible and belonging. There are 12 items on this scale with four response options namely strongly disagree, disagree, agree and strongly agree.

\section{Procedure}

The researcher looked for individuals who were in accordance with the criteria, i.e Syarif Hidayatullah State Islamic University active students and from outside Jakarta, Bogor, Depok, Tangerang and Bekasi. And then students who fit the criteria and sign inform consent are allowed to work on the questionnaire.

\section{Analysis}

The first thing the researchers did was regression analysis to see the effect of independent variable on dependent variable. Then researchers see the significance of the regression results that have been done using the $\mathrm{F}$ test. The model is said to be significant if it has a significance level of $<0.05$. Furthermore, the researchers also conducted tests to determine each IV which was significant for DV. This submission is done by means of a $\mathrm{t}$ test, which is to see the significance level of each IV.

\section{Result}

Regression analysis produces R-Square value of 0.457 . The amount of R-Square can be seen in table 1 .

Table 1: R Square.

\begin{tabular}{llc}
\hline Model & R Square & $\begin{array}{c}\text { Std. Erros of the } \\
\text { Estimete }\end{array}$ \\
\hline 1 &, 457 & 6,58561 \\
\hline
\end{tabular}

Furthermore, in the second step it was found that the significance level (p) in this study was 0,000 . The results of the F test can be seen in table 2: 
Table 2: ANOVA.

\begin{tabular}{cccc}
\hline & Sum of Squares & F & Sig. \\
\hline Regression & 8107,777 & 20,771 & .000 \\
Residual & 9628,192 & & \\
Total & 17735,969 & & \\
\hline
\end{tabular}

The third step is to see the significance of whether or not the regression coefficients of each independent variable, through the $t$ test. It was found that there were four independent variables with $\operatorname{Sig}<0.05$, namely emotion-focused coping, less useful coping, tangible and belonging. The results can be seen in table 3 :

Table 3: Regression Coefficient.

\begin{tabular}{|c|c|c|c|}
\hline & B & $\mathrm{t}$ & $\mathrm{Sig}$ \\
\hline$\overline{\text { (Constant) }}$ & $\begin{array}{l}12,65 \\
2\end{array}$ & 2,866 & ,005 \\
\hline Problem-Focused Coping &, 113 & 1,613 & , 108 \\
\hline Emotion-focused coping & ,279 & 4,024 &, $000^{*}$ \\
\hline Less Useful Coping &,- 177 & $-3,419$ &, $001 *$ \\
\hline Appraisal &, 036 &, 572 &, 568 \\
\hline Tangible &, 155 & 2,254 &, $025^{*}$ \\
\hline Belonging & 371 & 5,464 & $.000^{*}$ \\
\hline Semester &,- 467 & $-1,456$ & , 147 \\
\hline Gender & 1,288 & 1,341 &, 181 \\
\hline Social Status &,- 141 &, 581 &, 562 \\
\hline
\end{tabular}

\section{Discussion}

This study aims to determine the factors that influence the psychological well-being of overseas students Syarif Hidayatullah State Islamic University. These factors include coping strategies (problem-focused coping, emotionfocused coping and less useful coping), social support (appraisal, tangible and belonging) and demographics (semester, gender and social status). The results showed that there was a significant effect of coping strategies (emotion-focused coping and less useful coping) and social support (tangible and belonging) on psychological wellbeing overseas students Syarif Hidayatullah State Islamic University. Whereas for coping strategies (problem-focused coping), social support (appraisal) and demographic factors (semester, gender and social status) did not have a significant effect on psychological well-being of the overseas students Syarif Hidayatullah State Islamic University. Based on the research conducted in general, the coping strategy variables have a significant effect on the psychological well-being of the overseas students Syarif Hidayatullah State Islamic University. This research is in line with previous research conducted by Ryff \& Keyes [23], Huppert [14] where the use of coping strategies has a significant effect on the psychological well-being of students. Therefore, it is necessary to have a coping strategy to be able to improve the psychological well-being of overseas students.

Furthermore, when viewed from the regression coefficients of each coping strategy variable, there are two variables that have a significant effect, namely emotion-focused coping with a positive relationship and less useful coping with a negative relationship. Emotion-focused coping is an attempt to reduce or manage the emotional stress associated with a situation, aiming to reduce or regulate negative emotions caused by pressing situations [24]. This is in line with the theory described by Qiao [9] which states that there is a positive relationship between emotion-focused coping towards psychological well-being.

The second variable of the coping strategy that has a significant effect is less useful coping with a negative relationship. Less useful coping is a reduction in effort to overcome problems and transfer to an activity. This is in line with the theory explained by Qiao [9] that the use of less useful coping has a significant effect on the decrease in psychological well-being of individuals.

Based on research conducted in general, social support factors have a significant effect on psychological well-being of overseas students Syarif Hidayatullah State Islamic University. This result is in line with the research conducted by Turner [12], Malkoç \& Yalçin [14], and Cohen et al. [25] in their study found that social support has a significant influence on the individual psychological well-being. Likewise with Lee, Koeske, \& Sales; Misra, Crist, \& Burant [26]; Carver et al. who stated social support as one of the most important components for pyschological well-being of overseas students [27]. 
Furthermore, when viewed from the regression coefficients of each social support variable, there are two variables that have a significant effect, namely tangible and belonging, both of which have a positive relationship. Tangible is the availability of material assistance. Whereas, belonging is the availability of other individuals who can be relied upon when individuals want to do a joint activity [10].

In this study it was also found that problem focused-coping, appraisal, gender, semester and social status did not significantly influence psychological well-being of overseas students.

\section{Conclusion}

Based on the results of the research data analysis, it was concluded that there were significant effects of the coping strategy, social support and demographic factors on the psychological well-being of the overseas students Syarif Hidayatullah State Islamic University. The influence given is $45.7 \%$.

When viewed from the significance of the regression coefficients of each independent variable, there are four variables that have been shown to significantly influence pyschological well-being, namely emotionfocused coping, less useful coping, tangible and belonging. While other variables that did not significantly influence psychological well-being were problem-focused coping, appraisal, semester, gender and social status.

\section{References}

[1] Nuralisa, Andriana., Machmuroh., \& Astriana, Selly. Hubungan antara adversity quotient dan dukungan sosial teman sebaya dengan penyesuaian diri mahasiswa perantauan tahun pertama fakultas teknik universitas sebelas maret Surakarta. Wacana Jurnal Psikologi, 8 (15), pp. 1-12. (2016)

[2] Bowman, N. A. The development of psychological well-being among first-year college students. Journal of College Student Development, 51(2), pp. 180-200. (2010). doi: 10.1353/csd.0.0118.

[3] Devinta, M.,Hidayah, N., \& Hendrastomo, G.,. Fenomena culture shock (gegar budaya) pada mahasiswa perantauan di Yogyakarta. Jurnal Pendidikan Sosiologi, pp. 1-15. (2015)

[4] Huppert, F. A. Psychological well-being: Evidence regarding its causes and consequences. Applied Psychology: Health and Well-being, 1(2), pp. 137-164. (2009). doi: 10.1111/j.1758-0854.2009.01008.x.

[5] Punia, Namrata., \& Malaviya, Renu. Psychological well being of first year college students. Indian Journal of Educational Studies: An Interdisciplinary Journal, 2(1), pp. 60-68. (2015)

[6] Lazarus, R. S., \& Folkman, S. Stress, appraisal and coping. New York: Springer Publishing Company. (1984)

[7] Gustem-Carnicer, J., \& Calderón. C. Coping strategies and psychological well-being among teacher education students. European Journal of Psychology of Education. 28, pp. 1127-1140. (2012) doi: 10.1007/s10212-012-0158-x.

[8] Gloria, A. M., Castellanos, J., \& Orozco, V. Perceived educational barriers, cultural fit, coping responses, and psychological well-being of latina undergraduates. Hispanic Journal of Behavioral Sciences, 27(2), pp. 161-183. (2005). doi: 10. $1177 / 0739986305275097$.

[9] Qiao, G., Hu, J., \& Li, S. Stress, coping, and psychological well-being among new graduate nurses in China. Home Health Care Management \& Practice, 23(6), pp. 398-403. (2011). doi: 10.1177/1084822311405828.

[10] Cohen, S., \& Hoberman, H. M. Positive events and social supports as buffers of life change stress. Journal of Applied Social Psychology, 13(2), pp. 99-125. (1983). doi: 10.1111/j.1559-1816.1983.tb02325.x.

[11] Sarafino, E. P., \& Smith, T. W. Health psychology: biopsychososial interaction-seventh edition. 7 ed. United States America: John Wiley \& Sons. (2011)

[12] Turner, R. J. Social support as a contingency in psychological well-being. Journal of Health and Social Behavior, 22(4), pp. 357-367. (1981)

[13] Batool, S., \& Ahmad, A. Impact of perceived social support on psychological well-being of teenagers. Science Journal of Psychology, 2014, pp. 1-6. (2013). doi: 10.7237/sjpsych/267.

[14] Malkoç, Asude., \& Yalçin, Ilhan.,. Relationships among resilience, social support, coping, and psychological well-being among university students. Turkish Psychological Counseling and Guidance Journal, 5(43), pp. 35-43. (2015)

[15] Jasinskaja-Lahti, I., Liebkind, K., Jaakkola, M., \& Reuter, A., 2006. Perceived discrimination, social support networks, and psychological well-being among three immigrant groups. Journal of Cross-Cultural Psychology, 37(3), pp. 293311. doi: $10.1177 / 0022022106286925$.

[16] Garcia; Manuel F. Martınez., Ramırez; Manuel Garcia., \& Jariego, Isidro Maya. Social support and locus of control as predictors of psychological well-being in Moroccan and Peruvian immigrant women in Spain. International Journal of Intercultural Relations, 26(3), pp. 287-310. (2002). doi: 10.1016/S0147-1767(02)00005-6.

[17] Bewick, Bridgette. Koutsopoulou, Gina., Miles, Jeremy., Slaa, Esther., \& Barkham, Michael.,. Changes in undergraduate students' psychological well- being as they progress through university. Studies in Higher Education, 35(6), pp. 633-645. (2010) doi: 10. $1080 / 03075070903216643$.

[18] Momtaz, Y. A., Ibrahim, R., Hamid, T. A., \& Yahaya, N. Sociodemographic predictors of elderly's psychological wellbeing in Malaysia. Aging \& Mental Health, 15(4), pp. 437-445. (2011) doi: 10.1080/1360 7863. 2010. 536141.

[19] Ahrens, C. J. C., \& Ryff, C. D. Multiple roles and well-being: sociodemographic and psychological moderators. Sex Roles: A Journal of Research, 55(11-12), pp. 801-815. (2006) doi: 10.1007/s11199-006-9134-8

[20] Ryff, C. D., \& Singer, B. Psychological well-being: meaning, measurement, and implications for psychotherapy research. Psychoterapy and Psychosomatics, 65, pp. 14-23. (1996) doi: 10.1159/0002 89026. 
[21] Kaplan, George A., Shema, Sarah J., \& Leite, Cláudia Maria A. Socioeconomic determinants of psychological wellbeing: the role of income, income change, and income sources during the course of 29 years. Annals of Epidemiology, 18(7), PP. 531-537. (2008). https://doi.org/ 10.1016/j. annepidem. 2008. 03.006.

[22] Baruch, G. K., \& Barnett, R. Role quality, multiple role involvement, and psychological well-being in midlife women. Journal of Personality and Social Psychology, 51(3), pp. 578-585. (1986). http://dx.doi.org/ 10.1037 /0022-3514. 51.3.578

[23] Ryff, C. D., \& Keyes, C. L. The structure of psychological well-being revisited. Journal of Personality and Social Psychology, 69(4), pp. 719-727. (1995). doi: 10.1037/0022-3514.69.4.719.

[24] Carver, C. S.,. You want to measure coping but your protocol's too long: Consider the Brief COPE. International Journal of Behavioral Medicine, 4(1), pp. 92-100. (1997)

[25] Cohen S., Mermelstein R., Kamarck T., \& Hoberman, H.M. Measuring the functional components of social support. In: Sarason I.G., Sarason B.R. (eds) Social Support: Theory, Research and Applications. Dordrecht: Martinus Nijhoff Publishers., pp. 73-94. (1985)

[26] Cicognani, Elvira.,. Coping strategies with minor stressors in adolescence: relationships with social support, selfefficacy, and psychological well-being. Journal of Applied Social Psychology, 41(3), pp. 559- 578. (2011). doi: 10. 1111/ j.1559-1816. 2011.0072 6.x..

[27] Carver, C. S., Weintraub, J. K., \& Scheier, M. F.,. Assessing coping strategies: A theoretically based approach, Journal of Personality and Social Psychology, 56(2), 267-283. (1989). doi: 10.1037 /0022-3514.56.2.267.

[28] Panahi, S., Yunus, A. S. Md., Roslan, S., Kadir, R. A., Jaafar, W. M. W., \& Panahi, M. S. Predictors of psychological well-being among malaysian graduates. The European Journal of Social \& Behavioural Sciences, 16(2), pp. 2067-2083. (2016). doi:10.15405/ejsbs.186.

[29] Cho, Jaehee., \& Yu, Hongsing. Roles of university support for internastional students in the United States; analysis of systematic model university identification university support, and psychological well-being. Journal of studies in International Education, pp. 1-17. (2014). doi: 10.1177/1028315314533606.

[30] Wang, C. D. \& Castañeda-Sound, C. The role of generational status, self-estee,, academic self efficacy, and perceived social support in collage students'psychological well-being. Journal of Collage Counseling 11, pp. 101-118. (2008). doi: 10.1002/ j.2161-1882. 2008. tb00028. X. 